\title{
THE PRODUCTION OF FORTALEZA'S METROPOLITAN SPACE AND THE INDUSTRIAL DYNAMIC
}

\author{
produção do espaço metropolitano de Fortaleza e a dinâmica industrial
}

Alexsandra Maria Vieira Muniz *

\begin{abstract}
Resumo
O atual período técnico-científico-informacional é basilar para compreender a reestruturação urbana e industrial, assim, evidenciamos neste estudo as metamorfoses no espaço metropolitano de Fortaleza,em curso nas últimas décadas, com ênfase no processo de industrialização, reflexo das políticas públicas e privadas que criam as condições favoráveis para reprodução ampliada do capitalismo. Com o questionamento norteador sobre como a atividade industrial participa da produção do espaço metropolitano, perpassando a questão da gestão e planejamento deste espaço e o papel do Estado, utilizamos dados secundários, notadamente do Instituto de Pesquisa e Estratégia Econômica do Ceará (IPECE),Instituto Brasileiro de Geografia e Estatística(IBGE) e da Federação das Indústrias do Estado do Ceará (FIEC),os quais somados à pesquisa de campo e bibliográfica permitiram analisar os resultados evidenciados.
\end{abstract}

Palavras-chaves:Espaço Urbano; Indústria; Metrópole de Fortaleza.

\begin{abstract}
The current technical-scientific-informational period is fundamental to understand urban and industrial restructuring. This study evidences the metamorphoses in the metropolitan space of Fortaleza, ongoing in recent decades, with an emphasis on the process of industrialization, reflecting on the public and private policies that create favorable conditions for the amplified reproduction of capitalism. With the guiding question about how industrial activity participates in the production of metropolitan space, touching on the issue of management and planning of this space and the State's role, we use secondary data, notably from the Institute for Research and Economic Strategy of Ceará (IPECE), the Brazilian Institute of Geography and Statistics (IBGE) and the Federation of Industries of the State of Ceará (FIEC), which together with the field research and the literature permitted the analysis of the results.
\end{abstract}

Key words: Urban Space; Industry; Metropolis of Fortaleza.

\begin{abstract}
Resumen
El periodo técnico-científico-informacional actual es basilar para la comprensión de la reestructuración urbana e industrial, así evidenció en este estudio las metamorfosis en el espacio metropolitano de Fortaleza, en curso en las últimas décadas, con énfasis en el proceso de industrialización, reflejo de las políticas públicas y privadas que crean las condiciones favorables para la reproducción expandido del capitalismo. Con la pregunta guía sobre cómo la industrial actividad participa en la producción del espacio metropolitano, pasando la cuestión de la gestión y la planificación de este espacio y el papel del Estado, utilizamos datos secundarios, en particular el Instituto de Investigaciones Económicas y Estrategias de Ceará (IPECE),Instituto Brasileño de Geografía y Estadística (IBGE) y la Federación de Industrias del Estado de Ceará (FIEC),los cuales sumado a la investigación de campo y la literatura permitió analizar los resultados resaltados.
\end{abstract}

Palabras Claves: Espacio Urbano; Industria; Metrópolis de Fortaleza.

(*) Lecturer on the Universidade Federal do Ceará - Campus do Pici, Bloco 911, CEP: 60.440-900, Fortyaleza (CE), Brasil. Tel: (+55 85) 3366-9855 - geoalexia@gmail.com 


\section{INTRODUCTION}

An analysis of the role developed by industry in the production of metropolitan space in Fortaleza instigated a reflection on the State's industrial policy regarding industrial centralization and the current spatialization of industrial capital, as well as its relationship to the process of metropolitanization. To this end, field research and literature were used, as well as statistical data.

Seeking to systematize our ideas the text is organized into a further two topics -Institutionalization, Planning and Management in the Metropolitan Region of Fortaleza (MRF): some brief remarks show evidence of the formation of the MRF, the planning and the need for management; Space and Industry in the MRF: the prominence of the MRF in the concentration of economic activities is analyzed, notably industrial activities and their consequences, considering the context of the city of Fortaleza and the current configuration of the metropolitan space.

According to Santos (1994:66) "metropolitan regions are areas where several cities interact very frequently and intensely as a way of incorporating other urban nuclei under the command of a central nucleus [...]", thus, "Fortaleza did not fit rigorously into this definition of a metropolis, neither did it constitute a metropolitan region in the generic sense of this concept in the 1970s" (AMORA, 1999:34), given the greater interaction of the main center with the distant areas.

Established by the Supplementary Act of 1973, which created the first Brazilian metropolitan regions, the MRF was composed of the cities: Fortaleza, Caucaia, Maranguape, Pacatuba, and Aquiraz.

Other municipalities became part of the MRF, due to the capitalist restructuring and State reforms that transferred the power of institutionalization and metropolitan management to the States.

By 2014 the MRF totaled fifteen municipalities, in other words, contrary to the previous law, which only allowed the creation of municipalities in the MR with the dismemberment of the original municipalities, Pacajus, Horizonte, Chorozinho, São Goncalo do Amarante, Pindoretama and Cascavel were incorporated under state law and recently the four cities of Paracuru, Paraipaba, Trairi, and São Luis do Curu were also included.

The space that composes the MRF is commanded by Capital, which expands and reaches the neighboring municipalities. It is the influence of the nucleus through the economic and social relations between the surrounding cities, some with more interaction, and others with little or none, but their inclusion is justified by political and administrative purposes.

In the incorporation of the municipalities that became part of the MRF, whether or not there was any metropolitan cohesion was not taken into account, however, according to Lencioni (2006:56) we need to "understand the difference between the process of metropolization - that has no awareness of political desires - and the institutionalization of metropolitan regions as expedient for territorial planning."

As the formation of the MR touches on the issue of planning and management, "planning [being] preparation for future management, seeking to avoid or minimize problems and expand the room for maneuver: management is, at least in part (...), putting into effect the conditions that planning and management are distinct and complementary"(LOPES, 2002: 48).

\section{PLANNING AND MANAGEMENT IN THE MRF}

Urban planning in Fortaleza follows the socio-historical and economic context of the city's formation and expansion, although it was implemented late, driven by the need to remedy the disorder and problems arising from the country's accelerated urbanization process. Thus, in the late nineteenth century there were plans for urban improvement, from the 1930s there were the plans for urban remodeling, followed by the physical-territorial master plans and integrated local development from the 1970s to the late 1980s, reaching the participatory master plans in 1988. 
For the purposes of this study, we have not discussed each of these periods and forms of planning, however, it is worth mentioning the development of the Integrated Development Plan for the Region of Fortaleza in 1972 (PLANDIRF), which had the main objective of reinforcing Fortaleza as a "industrial and tertiary (commerce, services and tourism) metropolis, based on the decentralization of industrial activities to consolidate the metropolitan structure" (ACCIOLY, 2008:196).

According to Pequeno (2009) "the metropolitan agglomeration is the accumulated result of the different vectors of metropolization, principally related to productive activities (industrial, touristic, commercial) and the forms of the production of dwellings".

However, the actions in the MRF did not seek metropolitan cohesion, as the "[...] integration of the other municipalities of the MRF is through road works, without any proposal for cooperation between them and Fortaleza regarding the creation of common services and shared urban functions" (ACCIOLY, 2008:196).

Although we are in the technical-scientific-informational period(SANTOS;SILVEI RA,2001:118), under financial capital, with a predominance of tertiary activities in the metropolises, we cannot ignore the role of industrial activity in the current configuration of the metropolitan space of Fortaleza.

The zoning of the metropolis of Fortaleza, which has one of its zones strictly for the industrial use of space, was already included in the Law of Land Use and Occupation (LUOS). The LUOS of Fortaleza of 03/12/75, which included aspects of zoning, the road system and the division of land, was prepared based on the PLANDIRF. In 1979 this law was replaced by law 5122-A, seeking an adjustment in the face of changes in the capital and the regulation at the federal level of the Law of Land Division (6.766/79). Law 5122-A presented the following zoning of the city: residential areas differentiated by density; zones and corridors of mixed-use; strictly industrial zones; areas of environmental preservation and scenic interest; and special zones for beaches and urban and institutional renewal.

According to Santos Jr. (1995:36), the countless criticisms and lack of success of the planning policy "meant that, from the mid-1970s, the Federal Government began to abandon attempts at integrated and globalizing planning, initiating what in the 1980s would be known as participative planning".

The 1988 the Federal Constitution enabled the greater participation of society as protagonists in decentralized planning, concomitantly granting municipalities greater autonomy for planning and management.

In 1992, the Urban Development Master Plan PDDU-FOR was passed: law 7.061/92. This plan was complemented by the LUOS (7987/96) that in addition to dividing the territory into three macro-zones, according to the existence of water and sewage infrastructure, also created micro-zones for the distribution of activities and services, which included an industrial area in the special areas.

In the midst of a process of de-industrialization / displacement of old industrial areas, as we shall see, it is worth mentioning the urban voids in the industrial peripheries resulting from abandonment or underuse of territories formerly focused on industrial production.

In defining the macro-zoning and the Zones of Special Social Interest (ZEIS), the Participative Master Plan of Fortaleza - PDPFor (2009) reflects these territories' need for special treatment. According to Article 122, the ZEIS cover the areas in the territory that demand special treatment in the definition of regulatory parameters for land use and occupation, overlying the zoning. In articles 124-133, the PDPFor (2009) foresees the classification of the ZEIS into three types: type 1 (land occupations / favelas), type 2 (housing estates and irregular / clandestine subdivisions) and type 3 (urban voids / underused lots).

Aside from the construction of several master plans, what has been observed so far is the lack of cohesion, planning and management in the metropolitan space under analysis and notably the 
PDPFor (2009), which highlights this fact when it is observed that there is a real lack of articulation between the planning of the capital and the municipalities that are now part of the MRF.

This is explicit in Chapter X, Article 55 of the PDPFor (2009), which deals with Fortaleza's metropolitan integration policy. When we analyze each of the paragraphs of this article for concrete achievements, we can say that little progress has been made. Article 56 of the PDPFor (2009), details the strategic action of Fortaleza's metropolitan integration policy. The interpretation of this article only confirms the lack of concrete proposals as it simply makes broad generalizations about the strategic actions of the integration policy of Fortaleza's metropolitan area.

According to Silva (2015:386), "with regard to socio-spatial reality, its institutionalization occurred before the process of metropolization manifest itself".

An attempted execution of integrated planning focused on the metropolitan space of Fortaleza can already be found in the 1990s, with the Planefor "created on the initiative of the private business sector (...), it was a plan of commitments between the public authorities and society (...), to identify and select the actions and projects to develop the MRF" (IPEA,2013). Although the Planefor gained recognition from the Deliberative Council of the MRF it did not achieve the institutional weight for the formatting of integrated planning and management of metropolitan space of Fortaleza.

The criteria that guided the city zoning for planning purposes in 2009 are already out of date; as is the LUOS, which has been in force since 1996 and already overlaps the Strategic and Participative Planning of Fortaleza 2040 as a basis for further actions. Instead of new plans, what is necessary is not only their adaptation given the changes taking place, but especially their feasibility and applicability. Through proper planning and management, it is possible better to manage the growth of the metropolitan space in Fortaleza, considering it as a unified whole, reflecting a metropolitan administration that does not neglect municipal autonomy and contributes to a better quality of life of the population.

When talking about the MRF, we are considering the 15 municipalities, namely: Fortaleza,C aucaia,Maranguape,Pacatuba,Aquiraz,Maracanaú,Eusébio,Guaiúba,Itaitinga,Chorozinho,Pacaju s,Horizonte,São Gonçalo do Amarante,Pindoretama e Cascavel. In these municipalities dynamic is intensified as part of the actions developed in the State of Ceara aimed at cooperation with the private sector, based on the construction of infrastructure, changes in production, training programs, the supply of cheap labor, tax incentives and other local attractions, revealing the search for their inclusion in the face of the current situation of global competitiveness.

Due to the reduction in public spending and the maximization in the offer of locational factors, known for Santos e Silveira(2001) as the battle of locations in the 1990s, incentives in Ceará were amplified, guided by capital restructuring, especially in the sectors of industry, tourism, services and export agribusiness based on irrigated agriculture (fruits, vegetables and flowers) and the agro-industry associated with it. This is the context in which the metropolitan space in Fortaleza finds itself, so the following analysis will address industrial development.

\section{SPACE AND INDUSTRY IN THE MRF}

On inserting itself in global transformations the MRF went through a redefinition and refunctionalization of its space, with an important expansion of the objectives and actions systems (SANTOS, 1988, 1996), giving it more fluidity. The production of the space of circulation, with the extension of the technical-scientific-informational environment (SANTOS, 1996), the mainstay of productive restructuring, is present in the MRF to fulfill various purposes, many of them outside of the demands of local people.

In the quest to develop the metropolitan conditions that are essential for the reproduction of capital and considering the linkage of metropolitanization to space, Lencioni (2006: 47) explains that "when we talk about metropolization, we are talking about a socio-spatial process, a process that prints metropolitan characteristics onto space." 
Although the metropolization in Fortaleza has its specificities, with the municipalities increasing reliance on the investment and infrastructure, urban facilities and services offered by the capital, a spatial fluidity is evident, meaning a greater mobility of capital, technology and the workforce, as well as the geographical dispersion of production accompanied by intensified flows of people and information, boosting tourism, agribusiness and modern industries implanted in other municipalities of the MRF.

To this end communication and transport technical systems compete (SANTOS, 1994.1996). State and federal highways in the MRF facilitate the flow between diverse spaces of natural (coast, mountains and sertão), social (middle-class neighborhoods, working-class neighborhoods, gated communities, and housing estates) and economic activities (leisure facilities, tourism, industry, trade, services etc.), although this is not accompanied by a de facto integration of the road network, with consequent improvements in the quality of the transport systems. In the MRF there is a great distance between the IBGE's definition of metropolitan regions as "a group of contiguous municipalities that are socioeconomically integrated to a central city, with public services and infrastructure in common", and what actually occurs.

An analysis of the data collected by the IPECE on the GDP and the Sectoral Structure reflects the transformations that the MRF is going through regarding the current productive investments.

According to this analysis of the ten municipalities with the highest GDP in 2011, among those that are part of the MRF, the following are noteworthy: Fortaleza (1st), Maracanaú (2nd) Caucaia (3rd), Eusébio (4th), São Gonçalo do Amarante (5th) Horizonte (6th), Maranguape (7th), Aquiraz (8th), Pacatuba (9th) and Pacajus (10th).

This differs from 2001, when Pacajus was ranked 5th for GDP; in 2011 São Gonçalo do Amarante occupied this position. Both municipalities were annexed to the MRF in the same year (1999) but the latter has demonstrated a considerable rise in GDP from $2001(4.5 \%)$ to $2011(51.71 \%)$ of $47.66 \%$. Among other factors, this is due to investments in the industrial sector of this municipality.

Accounting for $48 \%$ of the state's GDP in 2011, the capital has the largest share of the metropolitan GDP. In addition to demographic concentration (it is the largest city in Ceará in population and fifth in Brazil, in 2014 the population was estimated at 2,571,896 inhabitants in an area of $314,930 \mathrm{~km} 2$, with the highest population density among the country's capitals, $7786.4 \mathrm{inhab} / \mathrm{km}^{2}$ ), Fortaleza concentrates the investments in the MRF, even with the extension of the urban fabric and the decentralization that follows global logic.

With regard to productive activities in the MRF in 2011, Eusébio (51.97\%), São Gonçalo do Amarante (51.71\%), Horizonte (47.44\%) and Maracanaú (47.21\%) had a larger industrial GDP than the Capital (19.28\%) and the State of Ceará (22.22\%). Over half the industry in the State is in the MRF, accounting for $67.42 \%$ of the total active industries in Ceará. In 2012 there were 30,324 industries compared to 12,062 in 2002, in other words, an increase of 262 industries (MUNIZ, 2014). The latest data from IPECE (2014) indicates an increase of 4,439 active industries.

It was through the planned activities of the state via SUDENE (Superintendency for the Development of the Northeast) and BNB (Bank of the Northeast of Brazil) (34/18 and later FINOR (Investment Fund of the Northeast)), that tax and financial incentives were offered for the installation of industries in cities such as Maracanaú. In this way, the old industrial zones in the Capital began to share space with other attractions for the amplified reproduction of industrial capital.

The traditional industrial areas comprise av.Francisco Sá and districts in its surroundings; as well as the neighborhoods Antonio Bezerra, Mucuripe and Parangaba.Já current industrial zones are the Industrial District (DI) Maracanaú; the Industrial Zone of Eusebius; Industrial Zone Maranguape; Furthermore, we have the Industrial Axis Pacajus and Horizon and the Industrial Complex of Porto do Pecém, let's see: 


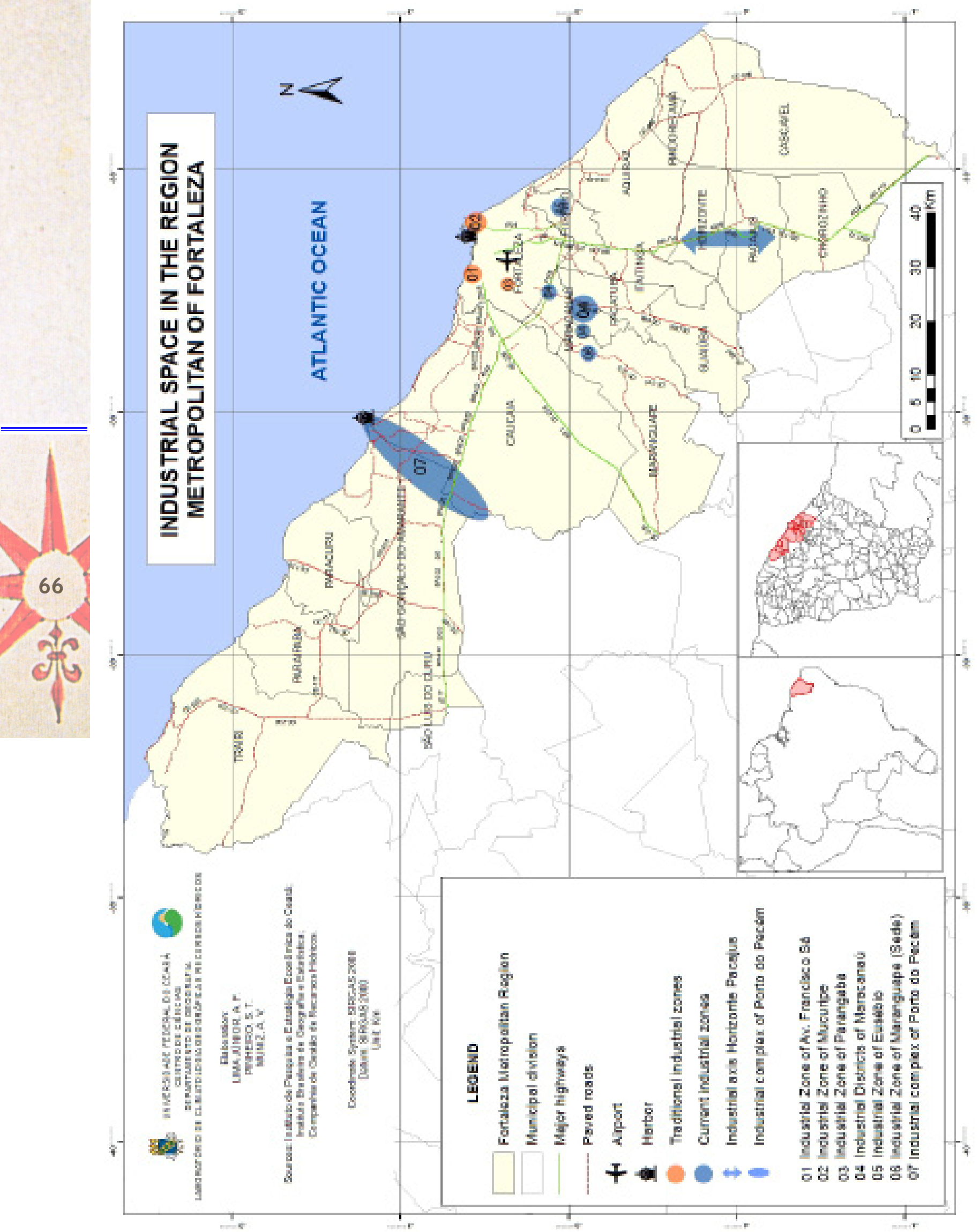

Figure 1 - Industrial Space in the Region Metropolitan of Fortaleza 
According to Firkowski (2008:57) the creation of industrial zones "aims simultaneously to disencumber central urban space and facilitate renovation [...]”. In the case of Fortaleza, it is worth remembering that the city has not always played a central role in the urban area of the state, as its primary role was to defend the territory and the administration (COSTA,2009:141). It was due to its cotton related activities that it conquered a new position in the urban network, from the nineteenth century, with the city's involvement in the exportation of cotton (DANTAS ET AL,2006:271).

With its industrial growth Fortaleza widened its functions. Until the 1970s, the greatest concentration of industry was in the neighborhoods of Mucuripe and Parangaba, on the Francisco Sá Avenue and neighborhoods along its route, as well as around the railway, attracting a large contingent of migrants.

This growth of the industrial zone of Francisco Sá was spontaneous and did not obey any urbanistic planning. The exodus of many industries left large territorial urban voids, including the old Urubu Workshop, of the now extinct Rede de Viação Cearense railway (RVC).

In the spaces that became urban voids due to industrial closure or relocation, fruit of the current industrial policy of the State of Ceará, the PDPFor (2009) has defined countless lots as ZEIS3. In this empty spaces left by former industries, the municipal administration is creating housing estates to relocate families living in risk areas or in precarious housing who were removed by the Vila do Mar Project. (MUNIZ, 2014).

Actions by City Hall, such as the above, interfere in the city's urban dynamic, using instruments foreseen in the Master Plan. Without also forgetting the importance of these actions in tackling the growing activity of the real estate sector, which has competed with the city government over the urban voids. This happens because of the investment opportunities in medium to high standard residential and commercial undertakings, with the presence of local facilities and services such as schools, health centers, banks, shopping malls, commerce and the excellent location of the Francisco Sá Avenue in the urban fabric, with transport that provides access to various locations in the city and MR.

With the industrial decentralization in the west zone of Fortaleza, a survey conducted by $\mathrm{Mu}-$ niz (2002) notes a spatial reconfiguration, a new function performed by this space that is no longer predominantly to maintain and value industry, whilst at the same time it is turning into residential space, with commerce and services. In the west there has been a growth in commercial sub-centers, aiming to distribute a range of products to a growing consumer market consisting predominantly of wage earners.

As a consequence of the inclusion of new spaces for industrial development, the Industrial District (ID) of Maracanaú - created in 1963, as the fruit of policies implanted by Virgílio Távora, the governor at the time - was part of the ambit of incentives for industrial development proposed in Ceará. "Installing and transferring the more polluting industries encouraged the growth of that District, guaranteeing the dynamic and expansion of the economy of the State of Ceará." (SILVA, 2009:20).

Currently, as well as textile industries((Aleze,Delfa,Fiotex,Pemalex,Karsten,Tecelagem Alphatex, Têxtil União,Filati, Beatriz and Jangadeiro Têxtil), Maracanaú has industries from various areas, such as metallurgy(Gerdau,Esmaltec) and mechanics(Durametal), paper and cardboard(Cobap), clothing(Rihomo,Norfabril), footwear(Polo), food and drinks(Frevo,Solar Refrescos,Colonial,Pelagio,Frut Biss), building services, and electrical and chemical materials. Maracanaú stands out among the municipalities of the RMF not only in industrial quantity $(1,509$ active industries), but also in the differentiation in the size, type of industry and products manufactured, as well as the number of employees.

Industrial activity in Maracanaú is accompanied by the concentration of other economic activities that in turn require services, including schools, banks, professional services etc. Thus, industry, commerce, and the banking and financial system work in an interdependent manner, with industrial 
activity acting as the motor of the municipality's economy, driving all the other activities. As stated by Lefebvre (1991:9) "[...] industrialization does not only produce businesses (workers and heads of businesses), but also diverse establishments, banking, financial, technical and political centers".

In addition to the installation of the infrastructure that facilitates continuous mobility and flows, the location of industries fosters job creation; it attracts much of the population that needs to be closer to the workplace and so ends up residing in the municipalities of the MRF. This also boosts the service sector, not only linked to industrial activities, but also aimed at the population who require of leisure and cultural facilities including schools, cultural and professional centers, shopping (Maracanaú has three shopping centers, as the North Maracanaú Shopping, Ponto do Shopping and the Feira Center) etc.

Moreover, the industrial district of Maracanaú has an excellent location close to the Ring Road, the highways and Fortaleza. The ID of Maracanaú is $18 \mathrm{~km}$ from Fortaleza's downtown area and $12 \mathrm{~km}$ from the Pinto Martins International Airport. In addition, it has a distribution structure for the ports of Mucuripe and Pecém; it is $26 \mathrm{~km}$ from the port of Mucuripe and access is on the CE-060 (linked by the Ring Road to the BR federal highways 116, 020, and 222 and the CE state highway 065).

The Maracanaú ID also has a qualified work force, both by the municipal administration and the IFCE (Federal Institute for Education in Science and Technology in Ceará), as well as the National Service of Industrial Training (Senai) that offers training courses. The construction of the Senai Institute of Technology (IST) will provide solutions for the development of the metal-mechanics sector in Ceará.

With an industrial GDP (47.21\%) higher than the state's, and as the third municipality in terms of population (209,057 inhab) Maracanaú contributes to a greater mobility of a large part of the population in the search for insertion in the labor market. This is evidence of the weight of industrial activity in the economy and the socio-spatial transformation in the municipality.

With the industrial corridor on the BR-116, the municipalities of Horizonte and Pacajus consolidated themselves as an industrial axis in the 1990s, as a result of the industrial policy adopted by the State. The FDI (Industrial Development Fund) was the main instrument to promote industrialization in Ceará, by adopting fiscal and financial incentives to attract new industries, notably through tax exemption or abatement.

As a consequence of this process, among the industries present in Horizonte (337 active industries), in addition to textiles((Santana têxtil and Têxtil Andina), there are also the footwear(Vulcabrás) and drinks industry(Schincariol,Cervejaria Nordeste). Pacajus has a total of 312 active industries, as well as the clothing branch of textiles(Vicunha, Arabril,Araujo e Brilhante,Malwee), there are also food industries, particularly those linked to the development of cashew related products(as Cajubraz and Sucos Jandaia).

As formerly the economies of Pacajus and Horizonte were based on commerce and agriculture, the cashew processing industries (fruit pulp and juice) and the packaging industries((Rigesa) are noteworthy, with the industries present in the industrial corridor of these two cities, the demand for packaging has been growing.

Analyzing the data in the Industrial Guide of Ceará - GIC (2014), the participation of the textile and clothing industry in the number of employees in Pacajus is clear; Malwee with 1,100 workers and Unit III of Vicunha Textils / A with 1,084 employees stand out. Whereas in Horizonte, besides the Santana textile company, with 1,000 employees, the highlight is the footwear industry, as Vulcabrás alone employs 11,000 workers.

According to MUNIZ (1999), many of the workers who formerly lived off of sporadic activities in the primary sector and then were absorbed as employees in the industries in municipalities that until then did not have an industrial vocation, adopted an urban pace of life in which discipline, punctuality and diligence became the values consistent with this new manner of working. These 
employees now have their identity and notion of space mediated between the workplace and their place of residence, unlike the pace of life they led before.

With the inclusion of new municipalities in the industrial vocation, industrial expansion has also occurred in the municipality of Eusébio, with 541 active industries, including the textile and clothing industries(Gurgel,Haco,Thunder,Adman,Cristal e Ramalho Têxtil), footwear (Mf manufacture and commercialization of footwear), drink(São Braz) and food (Três Corações,Pardal, especially the M. Dias Branco Group), and also construction industries(Paiva Engenharia,Plano e Sertegh Construções). The latter is due to rising real estate speculation, including luxury condominiums and gated subdivisions.

The creation of the Industrial and Port Complex of Pecém (CIPP) in 2002 strengthened the Caucaia-São Gonçalo do Amarante industrial axis and redefined the role previously played by these municipalities in the socio-spatial metropolitan structure. This has brought countless consequences for the metropolitan labor market, the mobility of the population and the demand for urban land, with the growth of the objectives and actions systems, leading to closer relationships between these municipalities and the Capital.

Among the industries already set up in the CIPP are those producing energy and others linked to construction, plus the food industry; most of them involve national capital and few jobs are generated in relation to the amount invested. Among the industries being implanted, according to an analysis of data from Ceará Portos (2015), are national and international industries. The capital invested in their operation is much greater than the capital invested in human resources and there are a high number of Korean workers, in other words, the importation of cheaper manpower and rising real estate speculation.

Among the industries installed and to be installed in the CIPP, the search to develop the industrial base in the State is apparent, so we have: Termoceará Ltda, Wobben Windpower Ind com. Ltda, Jatadois Ne Ltda, Votorantim Cimentos N / Ne S / A, Cement Industrial Company Apodi, Mpx-Pecem Power Generation S / A, CSP-Steel Company of Pecem, Ceara Steel S/A metallurgy, Fuhlander Energy Ltda Brazil, Eternit S / A, Aeris Energia S / A, Ceara Embalagens Ltda etc.

Caucaia, which also covers this complex, is the city in the state with the second highest amount of industry; there are a total of 1,639 active industries that include the textiles and clothing industries(Fio Jeitoso,Ondas,Sitec Têxtil), and chemical(Siqueira Gurgel) and metallic products(as the Aço Cearense, with 2,459 employees). Construction(Construtora Marquise S.A., with 3500 employees) is also important due to the municipality's large population and because of the growing real estate speculation with investments in primary residences where hitherto holiday homes were more common with the proximity of the coast and touristic attractions.

The municipalities of Chorozinho, Guaiúba and Pindoretama had the lowest activity in the industrial sector; in 2011 their industrial GDPs were lower than the state GDP. In 2001, the municipality with the lowest industrial GDP was São Gonçalo do Amarante, at the time the municipality was newly inserted into the MRF and suffered from a of lack of investment in this sector; currently the amount of industrial activity is very different.

Pacatuba benefits from the expansion of industries and housing estates initially concentrated in Maracanaú. There are a total of 368 active industries, including textiles and clothing(Marisol,Diuncorpo Lingerie,Zanotti), drinks(Aquavi,Mais Sabor), and packaging(Mecesa), among others. The presence of the company Marisol(Santa Catarina,Rio Grande do Sul and Ceará-Pacatuba) in this municipality is noteworthy, as it employs 1,575 people in this unit alone.

In Maranguape, there are a total of 690 industries, including textiles and clothing(Têxtil Itajaí do Nordeste,Hope do Nordeste,Micrel Benfio Têxtil,Banana Nanica,Arte Modas,Rosa de Sarom), food( Milk Maranguape ), electrical materials(Mallory), and footwear, with the strong presence of Dakota, which is one of the largest footwear manufacturers in Latin America; with its headquarters in Petrópolis/RS Dakota has seven factories distributed in the States of Rio Grande do Sul ( two units ), Ceará ( 4 units) and Sergipe (1 unit ). 
In the Maranguape unit Dakota provides direct employment to around 1,700 people (it also has a further three plants in Ceará, one in Russas with 3,200 workers, another in Iguatu with 1,643 employees and another in Quixadá, Mississipi Calçados).

In Aquiraz the main source of income is the service sector, especially tourism, but there is investment in industry, with a total of 402 industries, among them textiles and clothing(Tramix,Marinho Têxtil,Visual Uniformes), as well as food(Usibrás) and drink (Colonial). The last two have the greatest weight in the municipality in terms of job creation, as together they employ around 1,000 workers.

Cascavel has a total of 268 active industries, including textiles and clothing(Martêxtil,Herja, Bebevest), footwear(Cascavel Couros) and food(Cascaju). In interviews with residents during the field visit to Cascavel, it is clear that the industries Cascaju, with 924 jobs created, and Cascavel Couros, with 1,800 employees, play an important role in the municipality's economy. Even with the presence of manufacturing industries the municipality's economy is based on agriculture, notably the production of cashews, and commerce, with prominence to the Fair of São Bento, the second largest street market in Brazil, second only to the Fair of Caruaru, in Pernambuco. Cascavel's other sources of income are ceramic crafts and coastal tourism.

Guaiúba has 55 industries, among them clothing(Intuire), footwear(King Plastic), ceramics(Cerâmica Moreira) and packaging(Leo Pallets); however in addition to being small in number, these are small-scale industries without any prominent type of industry. During field work, the characteristics of rural space were evident in this municipality, which became part of the MRF after Pacatuba was broken up. There is a small amount of commerce in the city center, close to the main church, and there are animal husbandry and ceramics industries a short distance from the center.

On the other hand, in some municipalities that have no vocation for industrial development, there is a refunctionalization of space and a reinforcement of the urban lifestyle, reminiscent of Sposito (2010:126) regarding the redefinition of space and urban expansion with its consequent socio-spatial practices.

Unlike what was observed concerning the incorporation of spaces with rural characteristics, like Guaiúba, which are not truly integrated in the delimitation of urban metropolitan space in the capital, a diverse interest in a redefinition or urban configuration of this space is revealed. Above all there is the intent of attracting political-economic and administrative actions to specific segments.

In view of the main types of industries present in the metropolis we have perceived, among other things, how investment in industrial capital in the MRF takes place, leading us to affirm that the industries differ in the field in which they operate, in their size - there are small, medium and large industries - and in the origin of the capital invested, which no longer depends solely on local investments. On the other hand, the existence of foreign capital does not guarantee its permanence and both the quality of the jobs created and the flow of profits is questionable, prompting the need to develop studies of the current industrial policy of exemptions and the provision of a series of incentives to allocate national or international capital.

Of the total of 20,445 active industries in the MRF in 2012, 85\% are in manufacturing. When we analyze the representativeness of the manufacturing industry at the State level, we observe that of the total of 21,351 manufacturing industries in the State, more than half, namely $68 \%$, are concentrated in the MRF. According to the latest data from the Statistical Yearbook of Ceará (2014), the number of manufacturing industries in the State has been growing and today there are a total of 31,359 manufacturing industries in Ceará.

Moreover, even with the existence of industries based on new technologies, among the active manufacturing industries the greater part are the traditional genres, such as textiles and clothing, food and footwear that require a large workforce.

Therefore, it can be said that the spatial distribution of industry reflects and strengthens the process of metropolization and the State policy geared to the industrial sector that is developing in Ceará. Just as the process of metropolization drives the spread of industrial activity beyond the 
capital, the current industrial development in the metropolitan area of Fortaleza reinforces the metropolization in progress.

There is a preference on the part of modern and larger industries for municipalities near Fortaleza, the biggest amount of traditional industries have stayed in the Capital, some of these are in old spaces in the development of industrial capital((Iracema,Mecesa,Resibras,Grande Moinho Cearense s/a,J. Macedo s/a,Moinho Dias Branco s/a.,Cione,Empesca etc).

Although Fortaleza is not prominent in industrial GDP, it is the municipality with the largest representation in the services sector $(80.61 \%)$, the lowest in the agricultural sector $(0.2 \%)$, and the twelfth in the industrial sector (19.28\%), industry is concentrated in the Capital. Analyzing IPECE data on the use of industrial space in the MRF, of the total of 20,445 industries in the MRF in the past decade, it was evident that while all the municipalities have indicated industrial growth, the highest industrial concentration, with more than 15,000 industries, remains in the capital, accounting for $73.39 \%$ in 2012 .

On the other hand, although this amount has been increasing, and the last IPEC data (2014) points to an increase of 1,856 industries, bringing the total number of industries present in the capital to 16,861 , the pace of industrial growth Fortaleza is declining. The industry overflows to Maracanaú in the form of a zone and discontinuously to Pacajus and Horizonte as an axis; there is also the Industrial and Port Complex of Pecém, as previously reported, and numerous other industries that will locate themselves in the cities beyond the capital. The process of movement to the interior is observed when analyzing the industries that stand out in the State, such as footwear, which differs from the textile and clothing industrial sector that remains very focused on the capital and the metropolitan area (Muniz, 2014).

If in the plan for the MRF the concentration is on the Capital, since out of the total of 20,445 active industries in the MRF $85 \%$ are manufacturing and are concentrated in Fortaleza, representing $73.39 \%$, when considering the state of Ceará, the concentration is in the MRF, that is, industrial production occurs in a concentrated form in the MRF, despite the State Government's propaganda encouraging industrial interiorisation and despite the global industrial decentralization. More than half of the State's industry is in the MRF, representing $67.42 \%$ of the total active industries in Ceará.

The MRF transforms itself, not only, but also with industrial development. Industry in Fortaleza ends having more importance in metropolization than the metropolis has on industrial concentration, since the tendency for the start of de-concentration is already evident with the industrial relocation from old industrial areas in the capital and the slowdown in industrial growth in the capital with the industrial distribution to the MRF, contributing to metropolization. This is happens not only for the growing number of industries, but also the mobility of the workforce, the spatial circuits of production, and the cooperation circles inducing the creation of new centers.

Given the above, the current industrialization process favors changes in facilities and urban flows, resulting in new forms of spatial apprehension, since industrial emergence or relocation drives the process of metropolization, in addition to inducing the reinvention of urban spaces, revealing the recreation of the city of/for capital.

\section{FINAL CONSIDERATIONS}

The effort to synthesize the characterization of the current process of industrialization in the MRF, far from presenting space as a mere receptacle for a productive sector, discloses the insertion of municipalities as a product, condition and means for reproducing the industrial capital which materializes there, with significant changes both as regards the way of life of the population and the whole spatial rearrangement. The current State administration, by favoring some municipalities( as Maracanaú,Caucaia,Pacajus,Horizonte,Eusébio e São Gonçalo do Amarante) and attracting national and transnational industrial capital, has inserted new spaces in the circuit of industrial production, 
and has consequences, among other things, on the role performed by these cities in the industrial urban dynamic even if it takes place under the command the metropolis of Fortaleza.

The number of industries found during fieldwork in the 15 cities that make up the MRF show that industry is spreading beyond the capital, reinforcing the metropolization in progress not only because of the presence of industries in the cities that make up the MR, but mainly because the municipalities of MRF are spaces of production and reproduction in the process of capital accumulation.

Moreover, industrial investment in urban areas as well as boosting the process of metropolization of Fortaleza and the consequent expansion of its hinterland, favors the emergence of new centers, that is, this study shows little or no coordination and integration between the municipalities of the metropolitan space, but the trend with ongoing actions is to initiate such a process, although it requires more than isolated investments; it should consider the metropolis as a whole, because there is not, in fact, an economic and socio-spatial metropolitan reality, merely an outline of the trends in the expansion of the urban fabric, surpassing Fortaleza.

Aside from the potential of the metropolitan space of Fortaleza, this issue must be addressed to avoid falling in to the discourse and practice of a city without planning and management. This action should occur in the current term of the participative master plan through feasible policies in the short, medium and long term.

Metropolitan policies that take into account more than the spatial issue should be adopted. The administrative boundaries of the cities no longer reflect the physical, social, economic, cultural or environmental reality of the urban development, so there is a need for more flexible forms of governance.

It is also necessary to plan the installation of facilities, services and infrastructure geared to the particularities of the municipalities, taking into account the economic and historical-social training and the needs of the population who should not be seen only as cheap labor.

The industrialization policy adopted prioritizes economic growth, leaving us at the mercy of the interests of capital, but to speak of economic development one must look not only to GDP, but especially to the HDI (Human Development Index).

Faced with the State's inability to meet these challenges, it is necessary to build alternative forms of inclusion, involvement and coordination of all spheres of society and not only investment in one productive sector or another; the gains that some enjoy should be extended to include the majority.

To ensure the efficiency of the metropolitan administration, based on the implementation of the collectively built master plan, this instrument should promote development considering the multitude of aspects that concern the city and propose effective actions, with work plans and the power to articulate and mobilize trans-disciplinary teams.

It is necessary that the government and organized society as a whole make a commitment to materialize planning. Since multi-annual plans and annual budgets are the basic tools in municipal management, they should be incorporated into the master plan so that they are not relegated to the background or even "forgotten". As the application deadlines expire, as has occurred with the PDPFor, which has lost even more visibility after the launching of the Strategic and Participative Planning for Fortaleza 2040 that will certainly become the basis for drafting the new master plan.

Urban restructuring demands a profound revision of the relationship between the State, the private sector and civil society, where partnership and cooperation predominate. We need to monitor and oversee the effectiveness of the master plan through the link between the instruments of planning and management, and together, academics, researchers, managers and society as a whole unite in this purpose so that so that effectively there is a metropolitan government, because the master plan that should be the instrument of urban management has a number of gaps and we know that this is not an isolated case of the metropolitan space of Fortaleza.

Apart from the institutionalization of the cities that become part of the MRF and investments in the industrial sector aimed at the decentralization of capital, what we see is a real lack of concrete actions for metropolitan governance and a lack of articulation between the municipalities of the MRF. 


\section{REFERENCES}

ACCIOLY, Vera Mamede. Planejamento, Planos Diretores e expansão urbana: Fortaleza 1960-1992. Tese - Universidade Federal da Bahia. Programa de pós-graduação em Arquitetura e Urbanismo. Salvador, 2008. AMARAL FILHO, Jair do. (Org). Federalismo Fiscal e Transformações Recentes no Ceará. Fortaleza:INESP, 2000.

AMORA, Zenilde Baima (org). Indústria e espaço no Ceará. In: SILVA, José Borzacchiello da, CAVALCANTE, Tércia Correia, DANTAS, Eustógio Wanderley Correia. Ceará: um novo olhar geográfico. Fortaleza: Edições Demócrito Rocha, 2005.

AMORA, Zenilde Baima. Ceará: Enfoques Geográficos. Fortaleza: Funece, 1999.

DANTAS, Eustógio Wanderley Correia;SILVA, José Borzacchiello da; ZANELLA, Maria Elisa Zanella; MEIRELES, Antônio Jeovah de Andrade ( orgs.). Litoral e Sertão: natureza e sociedade no nordeste brasileiro. Fortaleza: Expressão Gráfica, 2006.

FIRKOWSKI, Olga Lúcia Castreghini de Freitas, SPOSITO, Eliseu Savério (orgs). Indústria, Ordenamento do Território e Transportes: A Contribuição de André Fisher. São Paulo: Expressão Popular, 2008.

LEFEBVRE, Henri. Industrialização e Urbanização. In: O Direito à cidade. São Paulo: Editora Moraes, 1991. LENCIONI, Sandra. Regiões metropolitanas do Brasil. Radiografia da dinâmica recente do emprego industrial e da remuneração do trabalhador. En publicación: América Latina: cidade, campo e turismo. Amalia Inés Geraiges de Lemos, Mónica Arroyo, María Laura Silveira. CLACSO, Consejo Latinoamericano de Ciencias Sociales, San Pablo. Diciembre 2006.

LENCIONI, Sandra. Reconhecendo metrópoles: território e sociedade. In: SILVA, Catia Antonia da, FREIRE, Désirée Guichard, OLIVEIRA, Floriano José Godinho de (orgs.). Metrópole: governo, sociedade e território. Rio de Janeiro: DP\&A: Faperj, 2006.

MOURA, Rosa. Institucionalização de Regiões Metropolitanas: qual o sentido? Revista Paranaense de Desenvolvimento. Curitiba, jul./dez. 2006.

Plataforma IPEA de Pesquisa em Rede; IPECE: PROJETO: Governança Metropolitana no Brasil, Relatório de Pesquisa, março de 2013.

PEQUENO, Luis Renato Bezerra (Org.). Como anda Fortaleza. Rio de Janeiro: Letra Capital. Observatório das Metrópoles, 2009.

SANTOS Jr., Orlando Alves dos. Reforma Urbana. Por um Novo Modelo de Planejamento e Gestão das Cidades. Rio de Janeiro: FASE/UFRJ-IPPUR, 1995.

SANTOS, Milton. SILVEIRA, Maria Laura. O Brasil: território e sociedade no início do século XXI. 9a ed. Rio de Janeiro: Record, 2001.

SANTOS, Milton; SOUZA, M. Adélia; SILVEIRA, M. Laura. Território, Globalização e Fragmentação. 4 ed. São Paulo: HUCITEC, 1998.

SANTOS, Milton. A natureza do espaço: técnica e tempo. Razão e emoção. São Paulo: Hucitec, 1996;

SANTOS, Milton. Técnica, espaço, tempo. Globalização e meio técnico-científico-informacional. São Paulo: Hucitec, 1994.

SANTOS, Milton. A Urbanização Brasileira. São Paulo: Hucitec, 1993.

SANTOS, Milton. Metamorfose do espaço habitado. São Paulo: Hucitec, 1988.

SILVA, José Borzacchiello da. Governança Metropolitana em Fortaleza. In: COSTA, Maria Clélia Lustosa, PEQUENO, Renato. Fortaleza: transformações na ordem urbana. Rio de Janeiro: Letra Capital: Observatório das Metrópoles, 2015.

SILVA, José Borzacchiello da. Formação Territorial Urbana. In: DANTAS, Eustógio Wanderley Correia, SILVA, José Borzacchiello da, COSTA, Maria Clélia Lustosa (Orgs.). Da cidade à metrópole: (trans)formações urbanas em Fortaleza. Fortaleza: Edições UFC, 2009.

SILVA, José Borzacchiello da. Características Gerais da Região Metropolitana de Fortaleza. In:DANTAS, Eustógio Wanderley Correia, COSTA, Maria Clélia Lustosa (Orgs.).Vulnerabilidade socioambiental na região metropolitana de Fortaleza. Fortaleza: Edições UFC, 2009. 
MUNIZ, A.

SILVA, José Borzacchiello da. Fortaleza, a metrópole sertaneja do litoral. In: SILVA, J. B.; DANTAS, EWC; ZANELLA, ME; MEIRELES, AJA. (orgs.). Litoral e Sertão: natureza e sociedade no nordeste brasileiro. Expressão Gráfica, 2006.

SILVA, José Borzacchiello da. A Região Metropolitana de Fortaleza. In: CAVALCANTE, Tércia Correia; DANTAS, Eustogio, SILVA, José Borzacchiello da. (Orgs.) Ceará: um novo olhar geográfico. Fortaleza: Edições Demócrito Rocha, 2005.

SOUZA, Marcelo Lopes de. Mudar a Cidade. Uma Introdução Crítica ao Planejamento e à Gestão Urbanos. 2.ed. Rio de Janeiro: Bertrand Brasil, 2002.

SPOSITO, Maria Encarnação Beltrão. Formas espaciais e papéis urbanos: as novas qualidades da cidade e do urbano. Cidades: Revista científica, v.7, n.11, 2010.

MÉO, Guy di. Introduction au débat sur la métropolisation : une clé de lecture pour comprendre l'organisation contemporaine des espaces géographiques.2008.

MUNIZ, Alexsandra Maria Vieira. A dinâmica da indústria têxtil no espaço metropolitano de Fortaleza. Tese. Programa de Pós-Graduação em Geografia da Universidade Federal do Ceará, UFC, Fortaleza, 2014. MUNIZ, Alexsandra Maria Vieira. As transformações do espaço urbano na zona da Francisco Sá. II Encontro de Pós-Graduação e Pesquisa da Unifor, Anais... Fortaleza-Ce, abril de 2002, p. 131, impresso.

MUNIZ, Alexsandra Maria Vieira. Aspectos infra-estruturais de Horizonte frente à reorganização espacial. In: Anais da IV Semana Universitária da UECE, Anais... Fortaleza, 1999. 